\title{
Health issues of incarcerated women in the United States
}

\author{
A questão da saúde nas mulheres encarceradas nos Estados Unidos
}

Sylvia Mignon ${ }^{1}$

\footnotetext{
${ }^{1}$ College of Public and Community Service,

University of Massachusetts Boston. 100 Morrissey Boulevard. 02125 Boston MA United States of America.

sylvia.mignon@umb.edu
}

\begin{abstract}
Health care within jails and prisons in the United States is typically insufficient to meet the medical and psychological needs of female inmates. Health services are often of low quality, especially in the areas of reproductive medicine. Mental illness, substance abuse, a trauma history, and sexual victimization while incarcerated can predict a more difficult adjustment to a correctional environment. Incarcerated women who are able to maintain contact with family members, especially children, can have a better prison adjustment. Recommendations are made to improve the types and quality of health care delivered to women in jails and prisons in countries around the world.
\end{abstract}

Key words Incarcerated women, Health care needs, Pregnancy in prison, Sexual victimization
Resumo A atenção à saúde em cadeias ou prisões nos Estados Unidos é claramente insuficiente para responder às necessidades médicas e psicológicas das mulheres encarceradas. Serviços de saúde são frequentemente de baixa qualidade, especialmente na área de medicina reprodutiva. Estresse, doença mental, uso de drogas, traumas psicológicos e abusos sexuais durante o encarceramento podem predizer maior dificuldade de adaptação ao ambiente prisional. Mulheres encarceradas que mantém contato com membros da família, principalmente crianças, tendem a melhor se adaptar. Recomendações têm sido feitas para melhorar o tipo e a qualidade da assistência oferecida às mulheres em cadeias ou prisões em países por todo o mundo.

Palavras-chave Mulher encarcerada, Necessidades de cuidados de saúde, Gestação na prisão, Vitimização sexual 


\section{Introduction}

Health care issues of women in jails and prisons in the United States generally have been ignored through history. Neither the health problems nor the quality of medical treatment provided to incarcerated women have been considered important and therefore have received little research attention ${ }^{1}$. This lack of attention has been rationalized by data that show there are fewer women than men in prison and therefore disproportionately fewer health resources are allocated to women.

The United States has had the highest rates of incarceration in the world since 2002, with women accounting for the greatest increase in numbers in recent years ${ }^{2}$. The increase in the number of women imprisoned since the 1980s is associated with drug crimes and property crimes ${ }^{3}$. Changes in gender roles for women that increasingly are similar to the roles of men, especially in the workplace, have been considered another reason that more women are incarcerated-women commit crimes previously only committed by men.

This article provides an overview of the health issues of American women in jails and prisons and the lack of responsiveness of correctional facilities to the health needs of incarcerated women. Rather than a theoretical or analytical effort, the purpose of the work is to provide a summary of the health concerns of incarcerated American women. Women's health conditions, including mental health and substance abuse problems are addressed, as well as pregnancy and birth while incarcerated. The article also offers recommendations that can improve the lives of women in jail and prison around the world.

The 1980s and beyond have been the time of mandatory prison sentences for drug crimes in the U.S., imprisoning far greater numbers of men and women-often these are prisoners with drug problems themselves ${ }^{1}$. In a review of the research, The Sentencing Project $(2012)^{4}$ found that between 1980 and 2010 there was a 646\% increase in the number of women in prison - an increase from 15,117 to 112,797 female inmates. Between 2000 and 2011 there was a $31 \%$ increase in the number of incarcerated women ${ }^{5}$. The increase in incarcerated women makes it even more important now to attend to the health needs of women in jail and prison. Yet, the increase in women in prison has not led to an increase in services. Overall, incarcerated women account for 6-8\% of the incarcerated population in the U.S. In the federal prison system currently $6.7 \%$ of inmates are women ${ }^{6}$.

Jail and prison inmates are typically from the lowest socioeconomic groups in society. Inmates in U.S. jails and prisons are much more likely to be poor women and men of color; this is also true of incarcerated populations around the world ${ }^{7}$. Women who are incarcerated can be considered "twice marginalized" because they are hidden from society and more professional attention is given to incarcerated $\mathrm{men}^{8}$. Far beyond the individual experiences of women in jails and prisons, incarceration of women can be seen as a tool of oppression against the poor and women of color that reflects racism, sexism, and classism ${ }^{7}$. The welfare and foster care systems, imprisonment, and deportation are ways to manage the poor in communities devastated by poverty, crime, and lack of resources ${ }^{9,10}$. The incarceration of mothers is even more damaging to families than incarceration of fathers since mothers are more likely to have responsibility for the care of children ${ }^{3,10,11}$.

Health issues and lack of medical and dental care in prison have long been problems for women in prison. Overall, quality and access are known to be poor. The prison environment is not conducive to good health. Food is often nutritionally deficient, there can be unclean physical surroundings, and inadequate physical activity can also have detrimental health effects ${ }^{12}$.

\section{Health Conditions of Incarcerated Women}

Women incarcerated in jails, state prisons, and federal prisons have significant health problems. In a sample of 154 incarcerated women, the initial health screening determined that $95 \%$ of women reported a minimum of one physical symptom $^{13}$. The most common problems upon admission were dental (87\%), menstrual cycle problems $(53 \%)$ chronic headaches $(38 \%)$, difficulty sleeping (34\%), and depression (33\%). Fifty-four percent were taking prescription medications at the time they entered prison ${ }^{13}$.

Based on data from the 2004 Survey of Inmates in State and Federal Correctional Facilities, $57 \%$ of female state inmates and $52 \%$ of federal female inmates reported that they had a medical problem at the time of the survey ${ }^{14}$. Women reported that their most common health problems were arthritis, asthma, and hypertension.

Overall, there has been a steady increase in the number of women reporting medical issues. The most recent data show that $67 \%$ of wom- 
en in jails and $63 \%$ of women in prisons report chronic health conditions ${ }^{15}$. Infectious disease rates are also high among women: $25 \%$ of women in prison and $20 \%$ of women in jails have had infectious diseases ${ }^{15}$.

Many incarcerated women do not have access to health care services prior to incarceration. This can be attributed to their low socioeconomic status and problems such as substance abuse, lack of good nutrition, and lack of preventive health care $^{16}$. Lack of medical care prior to incarceration also can mean more serious health issues, including chronic health problems ${ }^{16}$. Historically, many female inmates with serious chronic physical illnesses failed to receive care while incarcerated ${ }^{17}$.

The reproductive issues of women make the provision of health care more complicated for women than for men and are an additional challenge to health care services within prison walls ${ }^{1}$. These include menstruation, pregnancy, childbirth, breastfeeding, and menopause. The diagnosis and treatment of gynecological conditions can require specific medical equipment that may not be available in correctional facilities ${ }^{18}$.

A disproportionate number of women have been victims of sexual and physical abuse prior to incarceration and are at high risk for HIV/ AIDS, hepatitis $C$, as well as the human papillomavirus associated with cervical cancer ${ }^{3}$. Other sexually transmitted infections that women are at greater risk of having when they enter prison are chlamydia, gonorrhea and syphilis that are the associated with sexual victimization and prostitution $^{19}$

While the focus is most often on the health problems and stress of incarceration on women, for other women incarceration can provide a break from a grim daily existence. That is, for some women incarceration serves to bring some relief from chronic poverty, violence, and victimization $^{12,16}$

The concerns of older women in prison have largely been ignored ${ }^{20}$. Poor health and mental health services are of special concern to older women, especially coping with a terminal illness while in prison. Issues of safety for the elderly are also paramount when there is violence perpetrated by younger inmates ${ }^{20}$.

In general, inadequate healthcare and prison overcrowding are the most likely reasons to bring a lawsuit against a prison ${ }^{7,16}$. In Todaro v. Ward (1977), women in a New York prison brought suit because of lack of access to medical care ${ }^{16}$. In 1974, female inmates at the Bedford Hills Correctional Facility in New York filed a class action lawsuit against the New York State Department of Corrections in the U.S. District Court for the Southern District of New York ${ }^{21}$. The incarcerated women, represented by the Legal Aid Society, alleged that their constitutional rights had been violated by the failure to provide adequate medical care at the prison. In winning the lawsuit, the judge determined that medical care was inadequate; the decision was upheld on appeal. An ongoing federal lawsuit filed in Colorado in 2012 is pressuring prisons to offer improved mental health services to women and men and to severely restrict the use of solitary confinement ${ }^{22}$.

\section{Mental Health and Substance Abuse}

Clearly jails and prisons are highly stressful environments for inmates as well as staff ${ }^{23,24}$. Not surprisingly, there are higher levels of emotional distress in incarcerated women than in other women who are not in jail or prison ${ }^{25}$. Stress factors can often be traced to a history of child abuse and neglect, as well as the immediate environment in which individual women are placed ${ }^{23}$. Some women bring their mental health issues into the prison with them while other women develop mental health problems as a result of their incarceration $^{24,26}$.

In a study of 362 mothers in a maximum-security prison, stress was associated with depression, high levels of anxiety, greater complaints of physical problems, and significantly higher stress levels than non-incarcerated women ${ }^{27}$. Stress was also associated with having limited contact with children. A qualitative study of women in prison in the United Kingdom found that their mental health was negatively affected initially by the shock of incarceration, the concerns over being separated from family, and their upset over witnessing the behaviors of other women with serious mental illness or women in drug withdrawal $^{12}$

There are high rates of serious mental health problems in incarcerated women ${ }^{1,25,28}$. The most prevalent types of problems include trauma associated with a history of physical and sexual abuse, depression, and substance abuse ${ }^{1}$. Depression is the mental health problem that victims of trauma are most likely to develop ${ }^{9}$. High levels of anxiety and depression and behavior problems among incarcerated women are also associated with feelings of loss and inadequacy ${ }^{29}$.

As indicated, the mental health and addiction problems of incarcerated women are often associated with a history of childhood abuse and ne- 
glect ${ }^{30}$. Women with serious mental illness have been found to have more of all types of victimization as well as longer criminal records than those without an abuse history ${ }^{31,32}$. Both acute and chronic victimization can predict mental health issues during incarceration ${ }^{33}$.

The stress associated with a history of trauma can produce medical problems that become clearer or are exacerbated by imprisonment. In a qualitative study of mental health in a maximum-security prison, women who felt their mental health was worse than before their incarceration cited a number of problems ${ }^{24}$. These included stress, being away from family, fear, worry about physical health, insufficient mental health services and poor treatment by medical professionals and correctional staff. Certainly there is the likelihood that mental health problems that existed before incarceration can get worse without appropriate treatment ${ }^{24}$.

Substance abuse is a serious problem for women in jails and prisons in the United States $^{34,35}$. Trauma and addiction are intertwined but have been treated as separate problems? Drug and alcohol programs for women are more limited in number and often modeled on those for men $^{36,37}$.

Abuse and neglect must be acknowledged as health problems that need to be assessed and treated $^{23}$. Failure to address the mental health and substance abuse problems of incarcerated women can ensure the problems continue after release and include joblessness, homelessness, and the potential for loss of custody of children ${ }^{30}$. Another critical reason to treat mental health issues is that they can also be the strongest determinant of whether women return to prison ${ }^{38}$.

Mental health services in prisons can also be oriented around prescribed medications with a lack of opportunities for individual and/or group therapy. With too few mental health resources to go around, women can be made to feel in competition with other women for these services ${ }^{24}$. Importantly, women serving life sentences are often at the bottom of the list to receive health and mental health services. Segregation/solitary confinement can be inappropriately utilized for seriously mentally ill women and can exacerbate their problems $s^{39}$. Suicide can account for the majority of deaths among women inmates ${ }^{40}$.

Greater attention to meeting mental health needs can result in less stress for female inmates. In turn, this can reduce the stress levels of correctional staff and contribute to a less stressful prison environment ${ }^{24}$. Programs designed to address mental health issues in incarcerated women must also address parenting issues, especially whether the relationship should continue and then ways to maintain the relationship ${ }^{27,29}$. Mental health programs need to offer comprehensive services geared toward women's needs with an understanding of their backgrounds and prior lives?.

\section{Sexual Victimization in Prison}

Sexuality in prison and sexual violence have an impact on the physical and mental health of jail and prison inmates. Research interest in sexual violence in female correctional facilities did not develop until the mid-1990s $\mathrm{s}^{41,42}$. Yet, the paucity of research on sexuality in prison environments continues ${ }^{42}$.

Women in prison can suffer from post-traumatic stress disorder, related to prior and/or current sexual victimization. Those with an abuse history can re-experience their abuse by being searched or strip searched, having little to no privacy, feelings of isolation, and also having to cope with male correctional officers with authority over them ${ }^{13}$.

A study of sexual coercion among female inmates included interviews with 42 inmates, three of whom reported their own victimization ${ }^{43}$. Despite the small sample size and few acknowledgments of victimization, importantly this study did establish the topic as one worthy of research. A follow-up study by Struckman-Johnson and Struckman-Johnson ${ }^{44}$, with a much larger sample size of 263 female inmates, found between 6\% and $19 \%$ reported they had been sexually victimized. Importantly, inmates reported that $45 \%$ of victimizations involved prison staff. One review of the literature found that typically one-quarter of incarcerated women are sexually abused: "For incarcerated women, in particular, sexual assault, particularly guard-on-prisoner sexual assault, is simply a fact of life" 45 .

In a sample of 463 incarcerated women, $17.2 \%$ said they had been sexually victimized while in prison and $3 \%$ reported a completed rape $^{46}$. A whopping $68.4 \%$ of incarcerated women reported sexual victimization over their life course. Pardue et al. ${ }^{42}$ found that $4 \%$ of women had been victims of coerced sex while $2 \%$ admitted that they themselves had been perpetrators of sexual abuse.

There are different types of sexual victimization that include inappropriate touching and fondling, with completed penetration without consent as the most serious and damaging ${ }^{46}$. 
Standardized definitions of types of sexual assault have yet to be developed and can help in assessing and determining appropriate treatment, as well as assist in establishing comparisons among research findings ${ }^{46}$.

Services for victims of sexual assault may not be readily available to women in jails or prisons $s^{42}$. Of course, any kind of physical or emotional harm endured by women in prison should be treated by the correctional institution ${ }^{42}$. While hard to preserve privacy in prison, this serves as a reminder that more trained staff and better technological surveillance could reduce sexual victimization ${ }^{41}$.

\section{Pregnancy and Prison Birth}

Prison pregnancy and births create special challenges for a woman and for the correctional facility, especially prenatal care and arrangements for the birth of the baby. This presents a very difficult situation--it can be frightening for a woman to have to deliver her baby far from home without the support of family members.

One study found that 25 percent of women in prison were pregnant or had recently delivered a baby ${ }^{47}$. Approximately $4 \%$ of state and 3\% of federal inmates were pregnant at the time of admission to prison ${ }^{14}$. Of pregnant women entering state prisons, $94 \%$ received an obstetric exam, however, only $54 \%$ reported they received prenatal care ${ }^{14}$.

Not surprisingly, health care for pregnant women is of lower quality than that available to women in the community ${ }^{19}$. Prenatal and postnatal care are described by Roberts as "especially abysmal" 10 . Stories abound of inappropriate treatment of women during their labor and delivery, including women being forced to deliver their babies while shackled. The Justice Now program in Oakland, California has even documented cases of forced sterilization on female inmates ${ }^{10}$.

Not many women in U.S. prisons have the opportunity to have their infants remain with them during their first months of life ${ }^{48}$. Women who have had to give up their babies upon birth have reported that this contributed to their mental health problems $\mathrm{s}^{24}$. Perhaps the best-known prison nursery programs in the U.S. are found in the Bedford Hills Correctional Facility in New York and the Nebraska Correctional Center for Women, modeled after Bedford Hills. Over a 5-year period 42 women and their babies participated in the Nebraska program. Twenty-five percent of inmates surveyed felt they had strengthened their bond with their child as a result of their participation in the program ${ }^{29}$. Mothers who had less contact with their children and felt they had less influence in their children's lives, reported that they experienced greater emotional and physical distress. The majority of women will be released back to the community and will have responsibility for their children. From the perspective of the child's health, being deprived of a mother can lead to impaired physical and emotional development.

\section{Prison Visits}

Family relationships necessarily change when a woman is incarcerated. While in many cases women are cutoff from family, in other ways these connections become even more important to women in prison. In Finland, unlike the United States, it is possible under the Prisoner Sentences Act to postpone incarceration to address family difficulties and child care - it is even possible for a mother and father to serve sentences one after the other in order to take care of children ${ }^{49}$.

Nothing about the incarceration experience is designed to assist women to stay in touch with family members ${ }^{11}$. Women may not know where their children are or with whom they are staying $^{24}$. Challenges to maintaining connections with family include lack of transportation to institutions that are at a long distance as well as lack of funds to pay for transportation ${ }^{50}$. Telephone calls are typically hard to arrange and extremely expensive.

Contact with family members, especially children, can assist with adjustment to incarceration and help women better tolerate their confinement ${ }^{11}$. There are many opportunities for institutions to adjust prison visiting policies to better accommodate the needs of women and their families. Overall, family connections can help women experience a better transition from incarceration back to the community and reduce recidivism ${ }^{11}$. The greater use of "cyber-visiting" can offer a reasonable approach for incarcerated women to maintain family relationships ${ }^{50}$.

\section{Jail and Prison Health Services}

There is no incentive for correctional institutions to provide quality care to inmates ${ }^{51}$. Indeed, the fact that these health care consumers are incarcerated provides the incentive to restrict services and healthcare costs as much as possible. 
Correctional health care in the United States is often provided by private, profit-making corporations and today approximately 20 states utilize private companies ${ }^{52}$. Research does not show that privatization of health services for inmates is better than care provided by public agencies and indeed care can be worse ${ }^{53}$.

The New York Times, in a year-long investigation of the private company Prison Health Services, the largest provider of health services to the incarcerated at the time, documented the horrendous care and callow indifference to the health and mental health of inmates at the Rikers Island Jail in New York as well as the poor health care provided to children in the New York juvenile justice system ${ }^{54-56}$. These problems included provision of services by unlicensed and incompetent medical staff, physicians with criminal convictions, poor to no response to suicide attempts of inmates with death resulting, and horrific outcomes for inmates when medical staff failed to provide appropriate or any treatment. Prison Health Services merged with Correctional Medical Services in 2011 to form Corizon, now the largest private organization providing health care services in the U. S. ${ }^{52}$. Corizon now seems to be continuing the legacy of medical incompetence and disregard for the health of prison inmates. The mayor of New York City did not renew its contract with Corizon after a pattern of negligence that resulted in at least 12 deaths at the Rikers Island Jail ${ }^{57}$.

Inadequate and inappropriate care can be the result of political priorities, lack of funding, and institutional policies as well as the lack of competence of the medical professionals themselves, especially physicians and nurses ${ }^{16}$. The working conditions for medical professionals tend to be challenging for the doctors and nurses within a physically unpleasant and highly controlled environment. There is also the stigma medical professionals take on of serving low status patients and others may assume that they are less qualified than those who choose to work outside of a prison system ${ }^{16}$. The lack of adequate staffing can result in long delays in obtaining medical care within a reasonable time frame, a frustration for both inmates and health care providers.

Not surprisingly, inmates and medical personnel have different perspectives on health care services. Inmates tend to have negative views and see medical staff as judgmental, lacking empathy, lacking interest in helping them, and may feel abandoned ${ }^{16,24}$. A major source of complaints for women is the delay in receiving care. Medical staff tend to find their work especially challenging as they try to find the middle ground between providing treatment and adhering to the policies and practices of correctional facilities. Medical staff members are constantly reminded that health care is subjugated to the true purpose of the correctional facility - custody and safety of staff and inmates.

In some cases institutional policies indicate that treatment services are offered yet these may not be received by inmates ${ }^{16}$. The National Commission on Correctional Health Care publishes standards for correctional facilities to follow in providing health care. These standards are recommendations to manage medical and mental health care in the following institutions and programs: jails, prisons, mental health services, opioid treatment programs, and juvenile facilities. We are reminded that it is far easier to write policies and establish standards than to ensure that policies are implemented in ways that improve health care for inmates.

\section{Recommendations}

A variety of comprehensive services are needed to improve access to and the quality of health care services provided to women in jails and prisons in the U.S. The U.S. has much to learn from other countries regarding successful treatment and custody issues for incarcerated women and, in turn, other countries have much to learn from the U.S. The following are recommendations that can be utilized by any and all countries to improve women's health in jails and prisons:

1. Female offenders should be placed in the least restrictive correctional environments. Health and social services need to be improved and expanded to address the needs of female offenders in the effort to avoid incarceration. Incarceration of women, especially pregnant women, should be the last option and utilized only when an inmate poses a substantial risk to other individuals.

2. A health assessment upon admission should be mandatory in jails and prisons and must include pregnancy screening as well as screening for substance abuse, mental health problems, and a trauma history ${ }^{16,23}$.

3. Improve staff hiring and training to ensure that all custodial and medical staff are qualified for correctional work and require them to participate in gender-sensitivity training ${ }^{19,42}$.

4. Health services for incarcerated women need to be gender-specific and individualized to 
meet the needs of women. This includes hiring preferences given to female custodial and professional staff and the use of female chaperones during physical examinations ${ }^{19}$.

5. Testing for and treatment of infectious diseases, especially sexually transmitted infections, need to be a priority for the health and safety of all within correctional institutions ${ }^{16}$.

6. Standardized instruments and tools should be used to assess the psychological and substance abuse problems of incarcerated women. For example, the universal use of the AUDIT (Alcohol Use Disorders Identification Test) in correctional facilities can strengthen and facilitate comparisons among research findings. While we are a long way from this, the use of standardized tools will foster improved research studies to shed light on what works and what does not.

7. A multidisciplinary perspective is needed in combining theory and practice to design effective mental health and substance abuse treatment programs ${ }^{9}$.

8. Greater use of telemedicine. Incarcerated women are good candidates because they can be held in remote locations, lack medical services, and have the need for specialists due to reproductive issues ${ }^{1}$.

9. Develop more therapeutic communities for women with mental health and substance abuse problems within prison environments that simulate community living ${ }^{37}$.

10. Develop programs for terminally ill female inmates that can include placement in a community hospice program to ensure that the woman's medical and emotional needs are met ${ }^{58}$.

\section{Conclusions}

The health care needs of women in jails and prisons are complex; it is certainly a challenge to provide quality services within a system that emphasizes custody and control over treatment. Currently, the medical and psychological needs of women in jails and prisons are not being met in the United States. National, state, and local policy and practice undervalues women and especially fosters stigma of incarcerated women. Lack of gender equity in society and insensitivity to the needs of incarcerated women must be addressed in the U.S., and in every country, if social justice is an important goal. Federal and state courts will continue to be a very important source of advocacy for quality health care for incarcerated women.

Public health policies and standards to improve overall health in a society must also include improvements in prison health services. This requires a strong integrated health care network of competent professionals to provide quality medical care. Improved health care holds the potential to reduce trauma to incarcerated women, improve physical and psychological health, and benefit the women whether they are released back to the community or not. For the majority of women who are released, quality health care holds the potential to reduce recidivism and create healthier family systems. 


\section{References}

1. Anderson TL. Issues in the availability of health care for women prisoners. In: Sharp S, editor. Female prisoners in the United States: Programming needs, availability, and efficacy. New Jersey: Prentice Hall; 2002.

2. Tsai T, Scommegna P. U.S. has world's highest incarceration rate. Population Reference Bureau. 2012 August. [accessed 2015 Sept 25]. Available from http://www. prb.org/Publications/Articles/2012/us-incarceration. aspx

3. Braithwaite RL, Treadwell HM, Arriola KRJ. Health disparities and incarcerated women: A population ignored. J Public Health 2005; 95(10):1679-1681.

4. The Sentencing Project. Incarcerated women. 2012, revised September. [accessed 2015 Sept 25]. Available from http://www.sentencingproject.org/doc/publications/cc_incarcerated_women_factsheet_sep24sp.pdf

5. Minton T. Jail inmates at midyear 2011-Statistical tables. Washington: U.S. Department of Justice, Bureau of Justice Statistics; 2012. [accessed 2015 Sept 25]. Available from http://www.bjs.gov/content/pub/pdf/jim12st.pdf

6. Federal Bureau of Prisons. Inmate gender. 2015, August 29. [accessed 2015 Sept 25]. Available from: https:// www.bop.gov/about/statistics/statistics_inmate_gender.jsp

7. Eliason MJ, Taylor JY, Williams R. Physical health of women in prison: Relationship to oppression. Journal of Correctional Health Care 2004; 10(2):175-203.

8. Davis A. A world unto itself: Multiple invisibilities of imprisonment. In: Jacobson-Hardy M, editor. Behind the razor wire: Portrait of a contemporary American prison system. New York: NYU Press; 1999. p. ix-xviii

9. Bloom BE, Covington SS. Addressing the mental health needs of women. In: Gido R, Dalley L, editors. Women's mental health issues across the criminal justice system. Columbus: Prentice Hall; 2008. p. 160-176.

10. Roberts DE. Prison, foster care, and the systemic punishment of black mothers. Faculty Scholarship. Paper 432 2012. [accessed 2015 Sept 25]. Available from: http:// scholarship.law.upenn.edu/faculty_scholarship/432

11. Mignon SI, Ransford P. Mothers in prison: Maintaining connections with children. Social Work in Public Health 2012; 27(1):1-20.

12. Douglas N, Plugge E, Fitzpatrick R. The impact of imprisonment on health: What do women prisoners say? J Epidemiol Community Health 2009; 63(9):749-754.

13. Young D. Health status and service use among incarcerated women. Family and Comunity Health 1998; 21(3):16-31.

14. Maruschak LM. Medical problems of prisoners. Washington: U.S. Department of Justice, Bureau of Justice Statistics, 2008.

15. Maruschak LM, Berzofsky M. Medical problems of state and federal prisoners and jail inmates, 2011-12. Washington: Bureau of Justice Statistics; 2015.

16. Fearn NE, Parker K. Health care for women inmates: Issues, perceptions and policy considerations. Californian Journal of Health Promotion 2005; 3(2):1-22.

17. Wilper AP, Woolhandler S, Boyd JW, Lasser KE, McCormick D, Bor DH, Himmelstein DU. The health and health care of US prisoners: Results of a nationwide survey. Am J Public Health 2009; 99(4):666-672.
18. International Committee of the Red Cross. Health in prison: Looking after women in a man's world 2009 Feb. 27. [accessed 2015 Sept 25]. Available from: https://www.ocrc.org/engresources/documents/interview/women-health-prison-interview-020309.htm

19. van den Bergh BJ, Gatherer A, Fraser A, Moller L. Imprisonment and women's health: Concerns about gender sensitivity, human rights and public health. Bulletin of the World Health Organization. 2010. [accessed 2015 Sept 25]. Available from: http://www.who.int/ bulletin/volumes/89/9/10-082842/en/

20. Aday RH, Krabill JJ. Women aging in prison: A neglected population in the correctional system. Boulder: Lynne Rienner Publishers; 2011.

21. Open Jurist. 565 F. 2d 48 - Todaro v. Ward (1977). no date. [accessed 2015 Sept 25]. Available from: http:// openjurist.org/565/f2d/48

22. Blasius M. (2015, May 15). An attorney suing Supermax says the prison's conditions become torturous for inmates with psychiatric issues. [accessed 2015 May 15]. Available from: http://www.9news.com/story/news/local/ investigations/2014/05/14/treated-feds-change-mental-health-policy-after-supermax-lawsuit/9106157/

23. Goldkuhle U. Health service utilization by women in prison: Health needs indicators and response effects. Journal of Correctional Health Care 1999; 6(1):63-83.

24. Harner HM, Riley S. The impact of incarceration on women's mental health: Responses from women in a maximum-security prison. Qual Health Res 2013; 23(1):26-42.

25. Lindquist $\mathrm{CH}$, Lindquist $\mathrm{CA}$. Gender differences in distress: Mental health consequences of environmental stress among jail inmates. Behav Sci Law 1997; 15(4):503-523.

26. James D, Glaze L. Mental health problems of prisons and jail inmates. 2006. [accessed 2015 Sept 14]. Available from: http://bjs.ojp.usdoj.gov/content/pub/pdf/mhppji. pdf

27. Houck KDF, Loper AB. The relationship of parenting stress to adjustment among mothers in prison. $A m J$ Orthpsychiatry 2002; 72(4):548-558.

28. Jordan K, Schlenger WE, Fairbank JA, Cadell JM. Prevalence of psychiatric disorders among incarcerated women: II. Convicted felons entering prison. Arch Gen Psychiatry 1996; 53(6):513-519.

29. Carlson JR. Prison nursery 2000: A five-year review of the prison nursery at the Nebraska Correctional Center for Women. Journal of Offender Rehabilitation 2001; 33(3):75-97.

30. Messina N, Grella C. Childhood trauma and women's health outcomes in a California prison population. Am J Public Health 2006; 96(10):1842-1848.

31. Johnson KA Lynch SM. Predictors of maladaptive coping in incarcerated women who are survivors of childhood sexual abuse. Journal of Family Violence 2013; 28(1):43-52.

32. Lynch SM, DeHart DD, Belknap J, Green BL. Women's pathways to jail: Examining mental health, trauma, and substance use. BJA Policy Brief, NCJ241045. Washington: Office of Justice Programs, Bureau of Justice Assistance; 2013 
33. Lynch SM, Fritch AM, Heath NM. Looking beneath the surface: The nature of incarcerated women's experiences of interpersonal violence, mental health, and treatment needs. Feminist Criminology 2012; 7(4):381-400.

34. Hardy-Fanta C, Mignon SI. Alternatives to incarceration for substance abusing female defendants/offenders in Massachusetts, 1996-1998. Boston: University of Massachusetts, The Center for Women in Politics and Public Policy; 2000.

35. Mignon SI. Substance abuse treatment: Options, challenges, and effectiveness. New York: Springer Publishing Company; 2015.

36. Forman B, Larivee J. Crime, cost and consequences: Is it time to get smart on crime? Boston: Mass INC and Community Resources for Justice; 2013.

37. Mosher C, Phillips D. The dynamics of a prison-based therapeutic community for women offenders: Retention, completion, and outcomes. The Prison Journal 2006; 86(1):6-31.

38. Messina N, Burdon W, Hagopian G, Prendergast M Predictors of prison-based treatment outcomes: A comparison of men and women participants. Am J Drug Alcohol Abuse 2006; 32(1):7-28.

39. Codemo R. Women, prison and mental health-State (Illinois) deals with a troubled population in its corrections system. 2015 June 1 [accessed 2015 Aug 30]. Available from: http://wuis.org/post/women-prisonand-mental-health-state-deals-troubled-populationits-corrections-system

40. Coles D. Protecting the human rights of vulnerable women: A spotlight on deaths of women in prison. Probation Journal: The Journal of Community and Criminal Justice 2010; 57(1):75-82.

41. Hensley C, Castle T, Tewksbury R. Inmate-to-inmate sexual coercion in a prison for women. Journal of $O f-$ fender Rehabilitation 2003; 37(2):77-87.

42. Pardue A, Arrigo BA, Murphy DS. Sex and sexuality in women's prisons: A preliminary typological investigation. The Prison Journal 2011; 91(3):279-304.

43. Struckman-Johnson C, Struckman-Johnson D, Rucker L, Bumby K, Donaldson S. Sexual coercion reported by men and women in prisons. The Journal of Sex Research 1996; 33(1):67-76.

44. Struckman-Johnson C, Struckman-Johnson D. Sexual coercion reported by women in three Midwestern prisons. The Journal of Sex Research 2002; 39(3):217-227

45. Mardorossian CM. Victimhood in the carceral culture of women's prisons. International Review of Victimology 2012; 19(1):69-83.

46. Blackburn AG, Mullings JL, Marquart JW. Sexual assault in prison and beyond: Toward an understanding of lifetime sexual assault among incarcerated women. The Prison Journal 2008; 88(3):351-377.

47. Morton JB, Williams DM. Mother/child bonding. Corrections Today 1998; 60(7):98-104.

48. Yager S. Prison born. The Atlantic. 2015, Jul-Aug [accessed 2015 Aug 30]. Available from: http://www.theatlantic.com/magazine/archive/2015/07/prison-born /395297/
49. Enroos R. Mothers in prison: Between the public institution and private family relations. Soc Work 2011; 16:12-21.

50. Kates E, Mignon S, Ransford P. Parenting from prison: Family relationships of incarcerated women in Massachusetts. Boston: University of Massachusetts Boston, Center for Women in Politics and Public Policy; 2008.

51. Awofeso N. Making prison health care more efficient. BMJ 2005; 331(7516):575-576.

52. Dober, G. Corizon needs a checkup: Problems with privatized correctional healthcare. Prison Legal News. 2014 Mar 15 [accessed 2015 Sept 24] Available from: https://www.prisonlegalnews.org/news/2014/mar/15/ corizon-needs-a-checkup-problems-with-privatized-correctional-healthcare/

53. Tripp A, Holbrook N, Walen RC, Walsh RR. Tolerating failure: The state of health care and mental health care delivery in the Michigan Department of Corrections. Ann Arbor, Lansing: American Friends Service Committee and Prison Legal Services of Michigan, Inc; 2007.

54. von Zielbaur, P. As health care in jails goes private, 10 days can be a death sentence. The New York Times. 2005 Feb 27 [accessed 2015 Sept 21]. Available from: http:// www.nytimes.com/2005/02/27/nyregion/as-healthcare-in-jails-goes-private-10-days-can-be-a-deathsentence-sentence.htmal? $\mathrm{r}=0$

55. von Zielbaur, P. In city's jail, missed signals open way to season of suicides. The New York Times. 2005 Feb 28 [accessed 2015 Sept 21] Available from: http://www.nytimes.com/2005/02/28/nyregion/in-citys-jails-missedsignals-open-way-to-season-of-suicides.html

56. von Zielbaur P. A spotty record of health care at juvenile sites in New York. The New York Times. 2005, Mar 1 [accessed 2015 Sept 21]. Available from: http:// www.nytimes.com/2005/03/01/nyregion/01 jail.htm1 ei $=5070$

57. Pazmino G, Hamilton C, Goldberg D. De Blasio ends contract with Rikers health care provider. Politico. 2015, Jun 10 [accessed 2015 Sept 26]. Available from: http://www.capitalnewyork.com/article/city-hall/2015 /06/8569855/de-blasio-ends-contract-rikers-healthcare-provider

58. Barry EM. Bad medicine: Health care inadequacies in women's prison. Criminal Justice Magazine 2001; 16(1). [accessed 2015 Aug 30]; Available from: http://www. americanbar.org/publications/criminal_justice_magazine_home/crimjust_cjmag_16_1_barry.html
Artigo apresentado 30/09/2015

Aprovado em 07/04/2016

Versão final apresentada em 09/04/2016 
